\title{
Effect of fortified milk on growth and nutritional status in young children: a systematic review and meta-analysis
}

\author{
Misa Matsuyama ${ }^{1, *}$, Tracy Harb ${ }^{1}$, Michael David ${ }^{2}$, Peter SW Davies $^{1}$ and Rebecca J Hill ${ }^{1}$ \\ 'Children's Nutrition Research Centre, Child Health Research Centre, The University of Queensland, Level 6, Centre \\ for Children's Health Research, 63 Graham Street, South Brisbane, QLD 4101, Australia: ${ }^{2}$ School of Public Health, \\ The University of Queensland, Herston, QLD, Australia
}

Submitted 10 June 2016: Final revision received 4 October 2016: Accepted 18 0ctober 2016: First published online 12 December 2016

\begin{abstract}
Objective: Adequate nutrition is critical for optimal growth and development. However, young children may be at risk of nutrient deficiencies when transitioning to weaning foods for a variety of reasons. Supplementation with fortified milk may provide potentially lacking essential nutrients, but effects on growth and nutritional status are yet to be established.

Design: Five databases were searched for randomised controlled trials using fortified milk against control milk in young children. Outcomes were growth, body composition and/or biochemical markers. Pooled differences in means were calculated for continuous outcomes and odds ratios for binary outcomes.

Setting: Randomised controlled trials set in any country.

Subjects: Otherwise healthy children aged 6-47 months.

Results: Fifteen articles met the eligibility criteria. Fortification varied from Fe, Zn, vitamins, essential fatty acids, to pre- and/or probiotics. Frequently reported outcomes were weight, height and Fe status. Studies varied in geographical location, sample size and duration. Fortified milk had minimal effects on weight gain (mean difference $=0.17 \mathrm{~kg} ; 95 \%$ CI $0.02,0.31 \mathrm{~kg}$ ) compared with control milk. The risk of anaemia was reduced in fortified milk groups (OR $=0 \cdot 32 ; 95 \% \mathrm{CI}$ $0 \cdot 15,0.66)$ compared with control groups. There were no significant effects on height gain, changes in body composition or Hb concentration.

Conclusions: Fortified milk is an effective source of complementary nutrition to supplement children in need when consumed in appropriate amounts in addition to a normal diet. Due to compositional differences, further research on fortified milk is warranted before making global recommendations on benefits for growth and nutritional outcomes in young children.
\end{abstract}

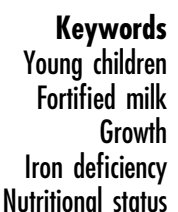

Young children have higher nutritional needs for growth and development, with increasing evidence supporting the importance of early-life nutrition on long-term health outcomes. The benefits of breast-feeding are unquestionable in the first 6 months of life; however, after weaning, dietary intake is not always optimal during the dietary transition period $^{(1)}$. A lack of access to adequate nutritious foods may be a direct contributory factor in suboptimal dietary intake, but the latter may also be due to food neophobia (i.e. fear of trying new foods) and 'picky/fussy' eating behaviour ${ }^{(2)}$. Researchers have identified that children with food neophobia have limited dietary variety $^{(3)}$ and picky eaters consume fewer vegetables ${ }^{(4)}$.
Cow's milk is one of the most commonly consumed and accepted food groups among young children, contributing the highest percentage of energy intake ${ }^{(5,6)}$.

Cow's milk is a rich source of $\mathrm{Ca}$, protein and fat; however, it is low in certain micronutrients important for growth and development, such as Fe. Fe deficiency is the most common micronutrient deficiency in the world ${ }^{(7)}$. Cow's milk is not only naturally low in Fe, but Ca has an inhibitory effect on Fe absorption. Young children are also at risk of deficiency of other nutrients such as vitamin $\mathrm{D}^{(8,9)}$ and $n-3$ essential fatty acids ${ }^{(10,11)}$, which are also low in cow's milk. In addition to being a poor source of key nutrients, excessive consumption of cow's milk may 
present other potential issues not conducive to optimal child growth, particularly the high protein content ${ }^{(12)}$. Studies have shown a link between high protein intake in early childhood and increased body fat and risk for later obesity $^{(13,14)}$. Childhood overweight and obesity is a serious global public health concern ${ }^{(15)}$.

Although consuming a balanced diet with a wide variety of nutritious foods is the best strategy to address nutrient deficiencies, unavailability of appropriate nutritious foods or fussy eating behaviours present a challenge to achieve optimal nutritional intake among young children. The WHO guidelines on improving infant and young child health and nutrition suggest using fortified foods when children are not achieving adequate nutrient intake from their diet ${ }^{(16)}$. Milk fortified with nutrients and/or with modified nutrient value is available and may be beneficial in meeting the nutrient requirements of some $1-3$-year-old children ${ }^{(17-19)}$. Thus far, the effect of fortified milk has not been systematically investigated. The purpose of the current systematic review and meta-analysis was to investigate the effect of fortified milk products compared with control milk in young children's growth and nutritional status outcomes, such as body size and composition, and/or biochemical markers.

\section{Methods}

The present systematic review was conducted in accordance with the guidelines of the Preferred Reporting Items of Systematic Reviews and Meta-analysis (PRISMA) statement ${ }^{(20)}$.

\section{Eligibility criteria}

Studies had to meet the following criteria to be included in the current review: (i) population was otherwise healthy children aged 6-47 months; (ii) intervention was fortified milk; (iii) control was cow's milk or non-/low-fortified milk; (iv) outcome was growth parameters and biochemical markers; and (v) study setting was a randomised controlled trial (RCT). Details are provided in Table 1.

\section{Search strategy}

We carried out the systematic computerised literature search in June 2014, using five electronic databases: PubMed (1951-), Web of Science (1900-), Embase (1966-), CINAHL
(1982-) and Cochrane Library (1996-). Only full original studies published in peer-reviewed journals in the English language, to minimise potential bias due to mistranslation, were selected. The search strategy incorporated the medical subject heading (MeSH) and the following search terms were used: ('growing up milk' OR 'fortified milk' OR 'followon formula') AND (NOT milk, human OR NOT 'breast milk') OR (probiotic*, prebiotic*, synbiotic*, symbiotic* AND milk) AND (child, preschool (MeSH) OR infant (MeSH) OR NOT infant, newborn (MeSH) AND growth). The term 'follow-on formula' was included because fortified milk for children older than 1 year of age can be referred to as 'follow-on formula'. The 'synbiotics' are a combination of pre- and probiotics, which is sometimes spelt 'symbiotic'. The term 'infant' was used as MeSH defines an infant as 'a child between 1 and 23 months of age'. Further hand-searching was also conducted from the citations in studies that met the eligibility criteria. One reviewer conducted the systematic literature search. All articles that matched the search terms were transferred to EndNote X7 (Thomson Reuters) and duplicates were removed.

\section{Study selection and data extraction}

Two reviewers independently screened titles and selected articles to review abstracts. Full articles were also screened independently based on relevance to the study question and eligibility criteria. One reviewer extracted data from selected articles based on the following variables: (i) lead author and year of publication; (ii) the age of children and country of origin (geographical setting of study); (iii) type of RCT; (iv) sample size including the number and percentage of participants completing the study, the number of participants with blood results, the type of milk and the amount consumed for the intervention and control groups; (v) the length of the intervention; (vi) adherence check, exclusion criteria and attrition information; (vii) baseline characteristics; and (viii) outcomes that were pertinent to the systematic review. Reported ages and lengths of intervention were converted to months. For studies that did not report outcomes that could be synthesised in a meta-analysis, efforts were made to contact the authors to obtain the data; but if authors did not respond to two requests, or were unable to provide

Table 1 PICOS table

\begin{tabular}{|c|c|}
\hline Population & $\begin{array}{l}\text { Otherwise healthy children aged } 6-47 \text { months. Initially, the eligible age was set at } 12-47 \text { months; however, due to the low } \\
\text { number of trials with this age limitation, trials that started at } 6 \text { months of age were also included in the review if at least } \\
50 \% \text { of the intervention was conducted and concluded during } 12-47 \text { months of age. The children in the studies had to } \\
\text { be free of known disorders (e.g. congenital disorder) or disease }\end{array}$ \\
\hline Intervention & $\begin{array}{l}\text { Fortified milk or formula with micronutrients and/or prebiotics, probiotics or synbiotics (i.e. combination of prebiotics and } \\
\text { probiotics), or had modified macronutrient content }\end{array}$ \\
\hline Comparison & $\begin{array}{l}\text { Non- (or low-) fortified milk or formula. Studies that had more than two trial groups were also eligible to be included in the } \\
\text { systematic review, including intervention other than milk, so long as the trial included intervention milk and comparator } \\
\text { milk groups }\end{array}$ \\
\hline Outcomes & $\begin{array}{l}\text { Growth parameters including body size (e.g. weight, height or length, BMI, head circumference), body composition and } \\
\text { biochemical markers (e.g. Fe, vitamin } \mathrm{D}, \mathrm{Zn})\end{array}$ \\
\hline Study design & Randomised controlled trial of minimum 4 months' duration conducted in young children \\
\hline
\end{tabular}


data, the article was excluded from meta-analysis. Three reviewers independently verified the extracted data. Meta-analysis was carried out under the guidance of a biostatistician. Risk of bias for individual articles was assessed using the modified Cochrane Collaboration's tool for assessing risk of bias in randomised trials ${ }^{(21)}$ with additional items relevant to the current review. For single studies with multiple published articles reporting different outcomes measured, data were extracted separately and the quality was assessed for each article independently.

\section{Meta-analysis}

The differences in means for continuous outcomes were calculated from baseline and outcome measures at the end of intervention for outcomes reported in arithmetic mean and standard deviation. If the study featured more than two intervention groups (i.e. intervention milk, control milk and another group), the intervention milk and the comparator milk that were most relevant to the review question were analysed. For example, if the study had two comparators, cow's milk or standard formula, then cow's milk was chosen as the comparator in meta-analysis. If the study reported outcome measurements at multiple time points, the measurement taken at the end of the intervention period and the corresponding number of samples were used. If the differences in means and 95\% confidence intervals were reported instead of standard deviations, standard errors were calculated assuming normal distribution ${ }^{(22)}$. A pooled odds ratio was calculated for cases of anaemia at the end of the intervention period. Anaemia was determined by the number of cases reported in each study. If anaemia was reported as a percentage, it was converted to numbers using the sample size reported. For zero-cell correction, 0.5 was added to all cells. Subgroup analyses were conducted based on the study country's economic status ${ }^{(23)}$, the intervention duration and the age of participants. Studies with $I^{2}>0 \cdot 40$ were analysed using the inverse-variance random-effects model, and forest plots were produced to illustrate the results. A funnel plot was produced to determine risk of bias across studies. The statistical software package Stata SE 13.1 was used to conduct meta-analysis.

\section{Results}

\section{Study selection}

A total of 514 titles were identified from the electronic search, and, after screening titles and abstracts, thirty-six full articles were retrieved. After screening, fifteen articles met the eligibility criteria to be included in the current review. The detailed literature search process is illustrated in Fig. 1.

\section{Study characteristics}

Fifteen articles based on twelve studies were included in the present systematic review ${ }^{(24-38)}$ (Table 2). The articles by Szymlek-Gay et $a l^{(34)}$, Morgan et $a l^{(28)}$ and Houghton et $a l .{ }^{(27)}$ were from a single study; and the articles by Morley et $a l .{ }^{(29)}$ and Singhal et $a l .{ }^{(32)}$ were also from a single study. Participant age was reported as median or mean; the youngest participants at baseline were 6 months and the oldest were 31 months. Four articles based on three interventions $^{(25,29,32,33)}$ enrolled children before 12 months of age and these interventions were from the UK. Length of intervention ranged from 4 to 12 months. In one study ${ }^{(26)}$, although the intervention length was 12 months, measurements taken at 4 months after the commencement of intervention were reported. Sex ratio was almost equal (close to $50 \%$ ) in seven studies; however, in one study ${ }^{(36)}$ the control group had a higher percentage of females $(81 \%)$. Four studies ${ }^{(25,31,33,38)}$ did not report the distribution of sex. The geographical setting of the studies varied. Of these, studies from India ${ }^{(31,38)}$, Indonesia ${ }^{(26)}$, Mexico ${ }^{(30,35)}$ and Vietnam ${ }^{(37)}$ were pooled as developing economies in subgroup analysis. Studies from New Zealand ${ }^{(27,28,34)}$, Sweden ${ }^{(36)}$ and the $\mathrm{UK}^{(25,29,32,33)}$ were pooled as developed economies. One study ${ }^{(24)}$ was set in multiple countries consisting of Malaysia, the Netherlands, Poland, Portugal and Thailand. The total sample size of studies at enrolment varied from $n 54$ to $n 767$. The most common fortificants were Fe and vitamin C, followed by Zn, essential fatty acids, vitamin D, and prebiotics, probiotics or synbiotics. The protein content of the milk was different between the intervention and control group in two studies, and the amount of milk consumed during the studies varied from 426 to $611 \mathrm{ml} / \mathrm{d}$. The control milk varied from standard cow's milk to no- or low-fortified 'follow-on-formula'.

Two studies were cluster RCT ${ }^{(30,37)}$, but both studies were adjusted for cluster effects; therefore, these studies were included in the meta-analysis. All studies were doubleblinded for milk groups except for one study, where the control group already consumed standard cow's milk prior to inclusion in the study and continued consuming this milk throughout the study ${ }^{(25)}$. Types of Fe used for fortification were ferrous sulfate ${ }^{(31-33)}$, ferrous gluconate $e^{(35,36)}$ and ferrous lactate ${ }^{(36)}$; the remaining studies $(25,30,34,37,38)$ did not specify the type of Fe used for fortification. Most studies collected dietary intake data including the consumption of milk, which in some cases was used as an adherence check to the study milk. Frequently cited exclusion criteria were cow's milk intolerance or allergy, congenital abnormalities, cardiac and renal issues, using regular medication and/or supplementation, and severe anaemia. However, not all studies excluded children with anaemia at baseline. Two studies $^{(31,38)}$ supplemented severely anaemic children with extra Fe for the first 3 months of the study in addition to their assigned milk. The operational definition of anaemia was not uniform, but mostly based on $\mathrm{Hb}$ concentration of $<110 \mathrm{~g} / \mathrm{l}$.

\section{Body size outcomes}

Seven articles ${ }^{(24,26,29,31,36-38)}$ reported outcomes in weight $(\mathrm{kg})$. Children in the intervention group had a 


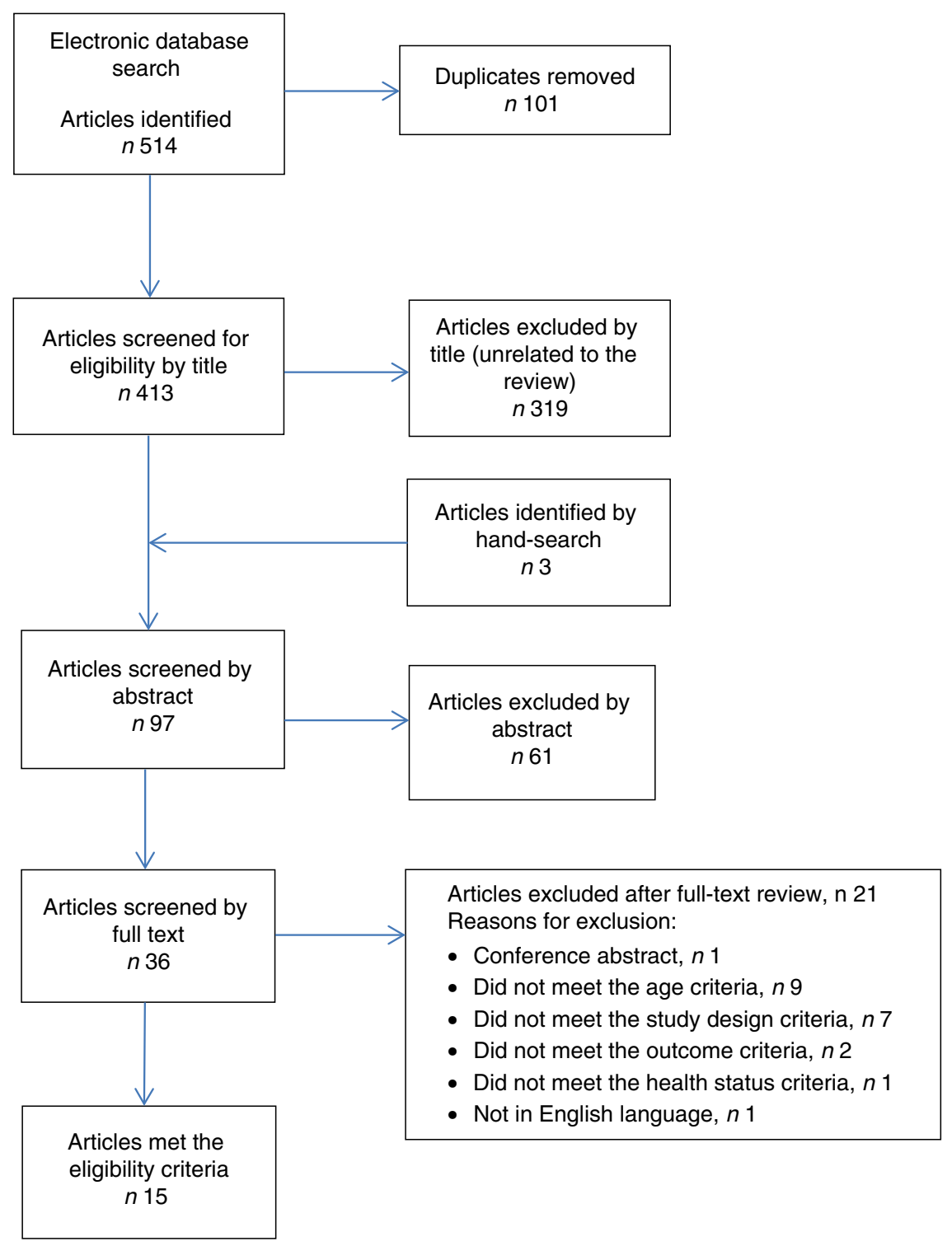

Fig. 1 (colour online) Flow diagram of the study selection process including the relevant number of papers at each stage and reasons for exclusion

statistically significant greater mean weight gain of $0.17 \mathrm{~kg}$ (95\% CI 0.02, $0.31 \mathrm{~kg}$ ) compared with the control group at the end of the intervention (Fig. 2). Two of the studies from developing economies ${ }^{(26,37)}$ reported average baseline weight-for-age $Z$-scores below zero. Studies based in India ${ }^{(31,38)}$ reported that $3 \cdot 5-6 \cdot 3 \%$ of children had weightfor-age $Z$-score $<-2$, which is classified as 'wasted' based on the WHO growth reference. Subgroup analysis for studies from developing economies ${ }^{(26,31,37,38)}$ of the difference in weight gain between the groups was $0.24 \mathrm{~kg}$ (95\% CI 0.02, 0.45 kg). Subgroup analysis for studies from developed economies was not conducted due to only having two studies reporting weight ${ }^{(29,36)}$. For studies with longer than 7 months' duration ${ }^{(24,29,31,38)}$, the mean difference in weight gain in the intervention group compared with the control group was $0.15 \mathrm{~kg}(95 \%$ CI $0.07,0.23 \mathrm{~kg})$, whereas for intervention length shorter than 7 months ${ }^{(26,36,37)}$ the mean difference was $0.22 \mathrm{~kg}(95 \% \mathrm{CI}-0.09,0.53 \mathrm{~kg})$. Subgroup analysis based on the age of participants was not conducted, as only one study ${ }^{(29)}$ that started its intervention before 12 months of age reported body size outcomes.

Length or height $(\mathrm{cm})$ was reported in six articles $^{(24,26,29,31,37,38)}$. However, the difference between the intervention group and control group in length or height gain from these articles, including subgroup analyses, did not reach statistical significance. Head circumference was reported in only two studies ${ }^{(26,29)}$; therefore, results were unable to be pooled for meta-analysis.

BMI was reported in three articles ${ }^{(24,26,37)}$. One arti$\mathrm{cle}^{(24)}$ reported that BMI was not statistically significant between the intervention and control groups. Another 


\begin{tabular}{|c|c|c|c|c|c|}
\hline Study & $\begin{array}{l}\text { Age at baseline*; country; } \\
\text { length of intervention }\end{array}$ & $\begin{array}{l}\text { Intervention milk; number and } \\
\text { percentage completing the study; } \\
\text { amount of milk consumed }+\end{array}$ & $\begin{array}{l}\text { Control milk; number and } \\
\text { percentage completing the } \\
\text { study; amount of milk } \\
\text { consumedt }\end{array}$ & $\begin{array}{l}\text { Study outcomes } \\
\text { investigated in the } \\
\text { systematic review }\end{array}$ & $\begin{array}{l}\text { Adherence check and other } \\
\text { comment }\end{array}$ \\
\hline Chatchatee et al. (2014) & $\begin{array}{l}19 \text { (14-24) months; multi- } \\
\text { country } \ddagger 12 \text { months }\end{array}$ & $\begin{array}{l}\text { LCPUFA, prebiotics; } n 348 \\
(90 \%) ; 528.8(128 \cdot 2) \mathrm{ml}\end{array}$ & $\begin{array}{l}\text { GUM without prebiotics } \\
\text { and LCPUFA; } n 349 \\
(92 \%) ; 527 \cdot 2(139 \cdot 2) \mathrm{ml}\end{array}$ & Weight, length, BMI & $\begin{array}{l}\text { Contacted parents every } \\
2-4 \text { weeks } \\
\text { CM group not randomised }\end{array}$ \\
\hline Daly et al. $(1996)^{(25)}$ & $\begin{array}{l}7.8(5 \cdot 7-8 \cdot 6) \text { months; UK; } \\
12 \text { months }\end{array}$ & $\begin{array}{l}\text { Fe, vit C, vit D; } n 41 \text { (82\%); mean } \\
\quad 480 \mathrm{ml}\end{array}$ & $\begin{array}{l}\mathrm{CM} ; n 43(86 \%) ; \text { mean } \\
\quad 584 \mathrm{ml}\end{array}$ & $\mathrm{Fe}(\mathrm{Hb})$ & Multiple 3 d WFR \\
\hline Firmansyah et al. (2011) & $\begin{array}{l}\text { IG } 12.4(0.21) \text { months, CG } \\
12.4(0.22) \text { months; } \\
\text { Indonesia; } 12 \text { months }\end{array}$ & $\begin{array}{l}\text { LCPUFA, synbiotics, lower } \\
\text { protein; } n 148(74 \%) ; 426 \\
(25.9) \mathrm{ml}\end{array}$ & $\begin{array}{l}\mathrm{CM} ; n 142(73 \%) ; 426 \\
\quad(31 \cdot 2) \mathrm{ml}\end{array}$ & $\begin{array}{l}\text { Weight, length, BMI, WFA } \\
Z \text {-score }\end{array}$ & $\begin{array}{l}3 \mathrm{~d} \text { records of milk intake } \\
\text { Protein was lower in } \\
\text { intervention milk }\end{array}$ \\
\hline Houghton et al. (2011) & $\begin{array}{l}\text { IG } 16.8(2.9) \text { months, CG } \\
16.8(2 \cdot 8) \text { months; New } \\
\text { Zealand; } 5 \text { months }\end{array}$ & $\begin{array}{l}\text { Fe, vit C, Zn, vit D; n } 43(96 \%) \text {; } \\
\quad 439-457 \mathrm{~g}\end{array}$ & $\begin{array}{l}\mathrm{CM} \text { with vit } \mathrm{A} \text { and vit } \mathrm{D} ; n \\
85(94 \%) ; 439-457 \mathrm{~g}\end{array}$ & Vit D & $\begin{array}{l}\text { Multiple } 3 \mathrm{~d} \text { WFR } \\
\text { Same study as Szymlek-Gay } \\
\text { et al. }\end{array}$ \\
\hline Morgan et al. $(2010)^{(28)}$ & $\begin{array}{l}\text { IG } 16.8(2.9) \text { months, CG } \\
16.8(2.8) \text { months; New } \\
\text { Zealand; } 5 \text { months }\end{array}$ & $\begin{array}{l}\text { Fe, vit C, Zn, vit D; n } 43(96 \%) \text {; } \\
\quad 439-457 \mathrm{~g}\end{array}$ & $\begin{array}{l}\mathrm{CM} \text { with vit } \mathrm{A} \text { and vit } \mathrm{D} ; n \\
85(94 \%) ; 439-457 \mathrm{~g}\end{array}$ & $\mathrm{Zn}$ & $\begin{array}{l}\text { Multiple } 3 \text { d WFR } \\
\text { Same study as Szymlek-Gay } \\
\text { et al. } \text {. }^{(34)}\end{array}$ \\
\hline Morley et al. $(1999)^{(29)}$ & $\begin{array}{l}\text { IG } 9.4 \text { (0.32) months, CG } \\
9.4 \text { (0.32) months; UK; } \\
9 \text { months }\end{array}$ & $\begin{array}{l}\text { Fe; } n 133(82 \%) ; \text { amount of milk } \\
\text { consumed NA }\end{array}$ & $\begin{array}{l}\mathrm{CM} ; n 160(96 \%) ; \text { amount } \\
\text { of milk consumed NA }\end{array}$ & $\begin{array}{l}\text { Weight, length, skinfold, } \\
\text { MUAC, Fe (Hb, sTfR) }\end{array}$ & $\begin{array}{l}\text { Multiple } 2 \text { d diet diary } \\
\text { Standard (unfortified) formula } \\
\text { group was also compared }\end{array}$ \\
\hline Rivera et al. $(2010)^{(30)}$ & $\begin{array}{l}\text { IG } 22.1 \text { (3.0) months, CG } \\
22.5(5.4) \text { months; } \\
\text { Mexico; } 12 \text { months }\end{array}$ & $\begin{array}{l}\text { Fe, vit C; n } 371 \text { (75\%); } 609 \text { (355) } \\
\text { ml }\end{array}$ & $\begin{array}{l}\mathrm{CM} ; n 213(78 \%) ; 611 \\
\quad(341) \mathrm{ml}\end{array}$ & $\mathrm{Fe}$ & $\begin{array}{l}\text { Adherence check NA } \\
\text { Only incidence of anaemia was } \\
\text { included in meta-analysis }\end{array}$ \\
\hline Sazawal et al. $(2010)^{(31)}$ & $\begin{array}{l}\text { IG } 22.4(6.8) \text { months, CG } \\
23.0(6 \cdot 7) \text { months; India; } \\
12 \text { months }\end{array}$ & $\begin{array}{l}\text { Fe, vit } \mathrm{C}, \mathrm{Zn} \text {, vit } \mathrm{D}, \mathrm{LCPUFA} \\
\text { B vitamins; } n 289(91 \%) ; 2.58 \\
\text { servings }\end{array}$ & $\begin{array}{l}\text { CM; } n 281(89 \%) ; 2.54 \\
\quad \text { servings }\end{array}$ & $\begin{array}{l}\text { Weight, length, WFA, WFL } \\
\text { \& LFA Z-scores, Fe (Hb, } \\
\text { SF, sTfR), Zn }\end{array}$ & $\begin{array}{l}\text { Checked consumption and } \\
\text { remaining milk }\end{array}$ \\
\hline Sazawal et al. $(2010)^{(38)}$ & $\begin{array}{l}\text { IG } 22.2(6.4) \text { months, CG } \\
23.0(6 \cdot 8) \text { months; India; } \\
12 \text { months }\end{array}$ & $\begin{array}{l}\text { Fe, vit C, Zn, vit D, LCPUFA, } \\
\text { B vitamins, synbiotics; } n 257 \\
\text { (82\%); amount of milk } \\
\text { consumed NA }\end{array}$ & $\begin{array}{l}\text { Fortified milk without } \\
\text { synbiotics; } n 245(79 \%) ; \\
\text { amount of milk } \\
\text { consumed NA }\end{array}$ & $\begin{array}{l}\text { Weight, length, WFA, WFL } \\
\text { \& LFA Z-scores, Fe (Hb, } \\
\text { SF, sTfR), Zn }\end{array}$ & $\begin{array}{l}\text { Checked consumption and } \\
\text { remaining milk } \\
\text { Both milks contained the same } \\
\text { amount of } \mathrm{Fe} \text { (excluded from } \\
\text { meta-analysis) }\end{array}$ \\
\hline Singhal et al. $(2000)^{(32)}$ & $\begin{array}{l}\text { IG } 9.4 \text { (0.32) months, CG } \\
9.4 \text { (0.32) months; UK; } \\
9 \text { months }\end{array}$ & $\begin{array}{l}\text { Fe, } n 133(82 \%) \text {; amount of milk } \\
\text { consumed NA }\end{array}$ & $\begin{array}{l}\mathrm{CM} ; n 160 \text { (96\%); amount } \\
\text { of milk consumed NA }\end{array}$ & $\mathrm{Fe}(\mathrm{SF}, \mathrm{sTfR})$ & $\begin{array}{l}\text { Multiple } 2 \text { d diet diary } \\
\text { Same study as Morley et al. }\end{array}$ \\
\hline $\begin{array}{l}\text { Stevens and Nelson } \\
\left(_{(1995)^{(33)}}\right.\end{array}$ & $\begin{array}{l}6 \text { months (range NA); UK; } \\
12 \text { months }\end{array}$ & $\begin{array}{l}\mathrm{Fe} \text {, vit } \mathrm{C} ; n \mathrm{NA} \text {; amount of milk } \\
\text { consumed NA }\end{array}$ & $\begin{array}{l}\mathrm{CM} ; n \mathrm{NA} \text {; amount of milk } \\
\text { consumed NA }\end{array}$ & $\mathrm{Fe}(\mathrm{Hb}, \mathrm{SF})$ & Adherence check NA \\
\hline $\begin{array}{l}\text { Szymlek-Gay et al. } \\
\qquad(2009)^{(34)}\end{array}$ & $\begin{array}{l}\text { IG } 16.8(2.9) \text { months, CG } \\
16.8(2 \cdot 8) \text { months; New } \\
\text { Zealand; } 5 \text { months }\end{array}$ & $\begin{array}{l}\text { Fe, vit } \mathrm{C}, \mathrm{Zn} \text {, vit } \mathrm{D} ; \text { n } 43(96 \%) \\
\quad 439-457 \mathrm{~g}\end{array}$ & $\begin{array}{l}\text { CM with vit A and vit D; } n \\
85(94 \%) ; 439-457 \mathrm{~g}\end{array}$ & $\mathrm{Fe}(\mathrm{Hb}, \mathrm{SF}, \mathrm{sTfR})$ & $\begin{array}{l}\text { Multiple } 3 \text { d WFR } \\
\text { Meat group was also } \\
\text { compared. Protein was } \\
\text { lower in intervention milk }\end{array}$ \\
\hline
\end{tabular}


$\operatorname{article}^{(26)}$ reported that BMI was slightly higher in the intervention group compared with the control group when the measurements were taken at 4 months after the study commenced. The third article ${ }^{(37)}$ reported that BMI among the intervention group remained normal for age compared with the control group, based on WHO reference data ${ }^{(39)}$.

Weight-for-age $Z$-scores were reported in four articles $^{(26,31,37,38)}$ and height- or length-for-age $Z$-scores were reported in three articles ${ }^{(31,37,38)}$. A study set in Indonesia $^{(26)}$ identified that among the intervention group, the change in weight-for-age $Z$-score from 12 months (baseline) to 16 months was in line with the WHO growth reference ${ }^{(39)}$. Two articles were based on studies conducted simultaneously in $\operatorname{India}^{(31,38)}$. In one of these studies $^{(31)}$, where the intervention group received micronutrient-fortified milk and the control group received standard cow's milk, it was shown that weight-for-height, weight-for-age and height-for-age $Z$-scores were significantly improved in the intervention group. In the other study ${ }^{(38)}$, both intervention and control groups received milk fortified with the same added micronutrient contents including $\mathrm{Fe}$, but the intervention milk had added synbiotics; probiotic Bifidobacterium lactis HN019 DR 10, as well as prebiotic oligosaccharides. In that study, the authors did not find a significant difference in the change in $Z$-scores between the intervention and control groups from baseline to end of the study. However, weight velocity was greater in children in the intervention group receiving milk with added synbiotics compared with children in the control group ${ }^{(38)}$. Another study ${ }^{(37)}$, which investigated the effect of milk fortified with synbiotics compared with milk without synbiotics, showed statistically significant differences between intervention and control groups for weight-for-age $Z$-scores $(P<0.001)$ and length-for-age $Z$-scores $(P<0.001)$, despite a short intervention duration of 5 months.

\section{Body composition outcomes}

Only one article ${ }^{(29)}$ reported anthropometry-derived body composition using mid-upper arm circumference and skinfold thickness. That study did not find any significant differences in body composition between the fortified milk group and the cow's milk group.

\section{Biochemical marker outcomes - iron}

Fe was the most investigated biochemical marker. Nine articles reported changes in $\mathrm{Hb}$ concentration $(\mathrm{g} / \mathrm{l})$ from baseline ${ }^{(25,29,31,33-38)}$. One article ${ }^{(38)}$ was omitted from meta-analysis for biochemical markers of $\mathrm{Fe}$ status because both the intervention milk and the control milk in the study were fortified with the same amount of Fe (approximately $5.4 \mathrm{mg} / \mathrm{d}$ ). Although the result did not reach statistical significance, the mean increase of $\mathrm{Hb}$ concentration in the intervention group compared with the 


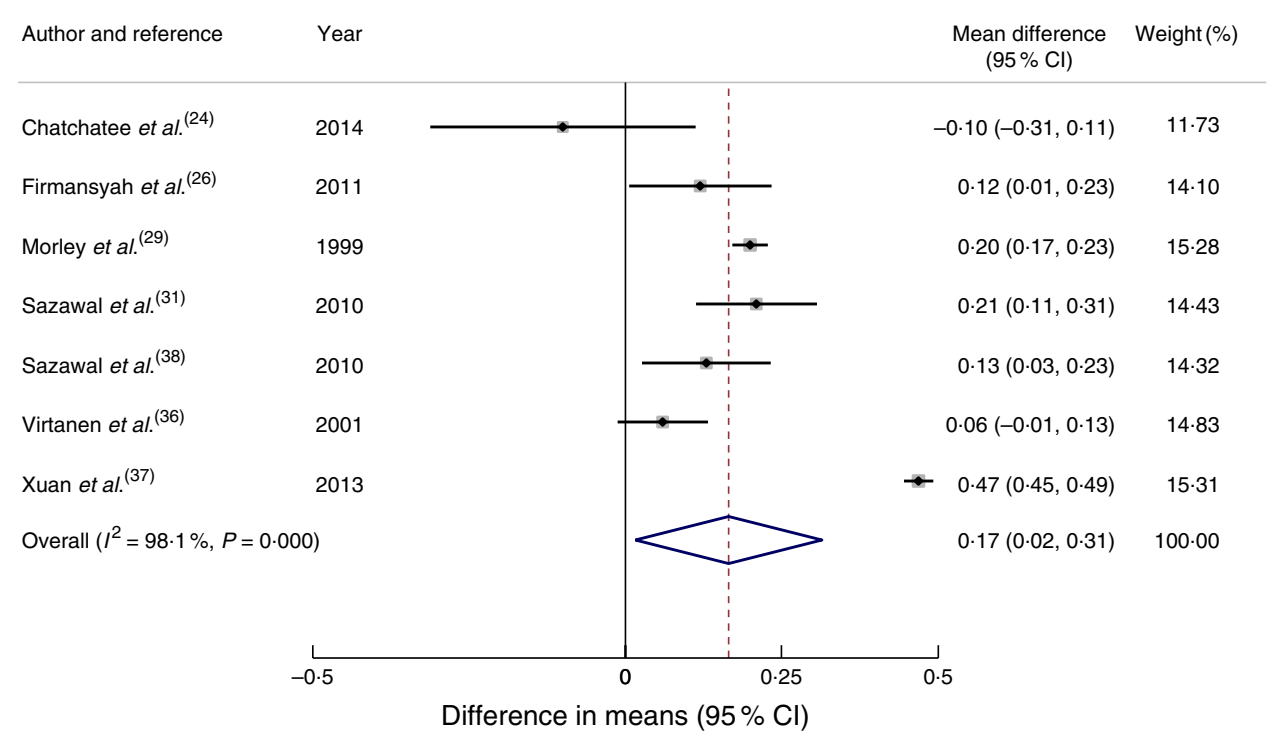

Fig. 2 (colour online) Forest plot: effect of fortified milk compared with control milk on mean difference in weight gain (kg) among 6-47-month-old children. The study-specific mean difference and $95 \% \mathrm{Cl}$ are represented by the black dot and horizontal line, respectively; the area of the grey square is proportional to the specific-study weight to the overall meta-analysis. The centre of the open diamond/vertical dashed line represents the pooled mean difference and the width of the diamond represents the pooled $95 \%$ Cl. The solid vertical line represents no effect

control group was $5.89 \mathrm{~g} / \mathrm{l}(95 \%$ CI $-0.24,12 \cdot 02 \mathrm{~g} / \mathrm{l}$; $P=0.06)$.

Serum ferritin and transferrin receptor concentrations were also reported, but because some of these values were reported as geometric mean ${ }^{(32,34,36)}$ or median ${ }^{(33)}$, or did not measure baseline values ${ }^{(32)}$, it was not possible to pool these results to calculate mean differences. Outcomes for serum ferritin levels and serum transferrin levels were inconsistent. Two articles reported an increase in serum ferritin levels among the fortified milk groups $^{(31,34)}$, whereas two other articles ${ }^{(35,36)}$ did not show a statistically significant difference between groups, albeit trends were apparent in one article ${ }^{(36)}$ for an increase in serum ferritin $(P=0.06)$ and decreased ratio of serum transferrin receptor to ferritin $(P=0.05)$ in the fortified milk group. One article $^{(33)}$ did not identify differences in median ferritin levels between the two groups. The intervention milk compared with the control milk had no effect on serum transferrin receptor concentration in two articles ${ }^{(34,36)}$, but it was reduced in two articles ${ }^{(31,35)}$. One article ${ }^{(32)} \mathrm{did}$ not report a baseline measure, but found higher serum ferritin levels among the fortified milk group, although there was no difference in serum transferrin receptor values.

Nine articles ${ }^{(25,29,30,31,33-37)}$ reporting cases of anaemia at the end of the intervention were pooled to calculate an odds ratio. The risk of anaemia was reduced significantly among the intervention group compared with the control group $(\mathrm{OR}=0.32 ; 95 \% \mathrm{CI} 0 \cdot 15,0 \cdot 66$; Fig. 3 ). Odds of anaemia among the intervention group compared with the control group in the subgroup analysis of developing economies $^{(30,31,35,37)}$ was $0.36(95 \%$ CI $0 \cdot 14,0.91)$ and for interventions longer than 7 months ${ }^{(25,29,30,31,34)}$ was $0 \cdot 17$ (95\% 0.09, 0.33). The odds for interventions less than
7 months' duration or studies conducted in developed economies did not reach statistical significance. To investigate the effect of age, removing three studies which started the study before 12 months of age ${ }^{(25,29,33)}$ resulted in an OR of 0.46 (95\% CI 0.19, 1.12).

Body Fe was investigated in one study ${ }^{(34)}$, which was higher in the fortified milk group compared with the control group. Other markers of $\mathrm{Fe}$ status such as $\mathrm{Zn}$ protoporphyrin, haematocrit and red-cell distribution width were investigated in one study ${ }^{(31)}$; these authors reported improvements in these markers among the fortified milk group. Mean corpuscular volume was investigated in two studies ${ }^{(25,36)}$. One study showed significant improvements in the fortified milk group ${ }^{(25)}$, but no difference was found in the other study ${ }^{(36)}$.

\section{Other outcomes}

Serum $\mathrm{Zn}$ was investigated in five articles $28,31,35,37,38)$. None of these studies identified a statistically significant change in serum $\mathrm{Zn}$ concentration as a result of feeding Zn-fortified milk. Vitamin D was investigated in one study set in New Zealand; however, both the intervention and control milks were fortified with vitamin $\mathrm{D}^{(27)}$. That study also had a red meat intervention group and compared with this group, both milk groups increased mean serum 25-hydroxyvitamin D concentration.

\section{Risk of bias}

The risk of bias within studies is shown in Table 3. More than half of the articles described the method of allocation sequence generation. It was not practicable to double-blind all participants in every study. Most studies addressed 
Fortified milk and child nutritional status

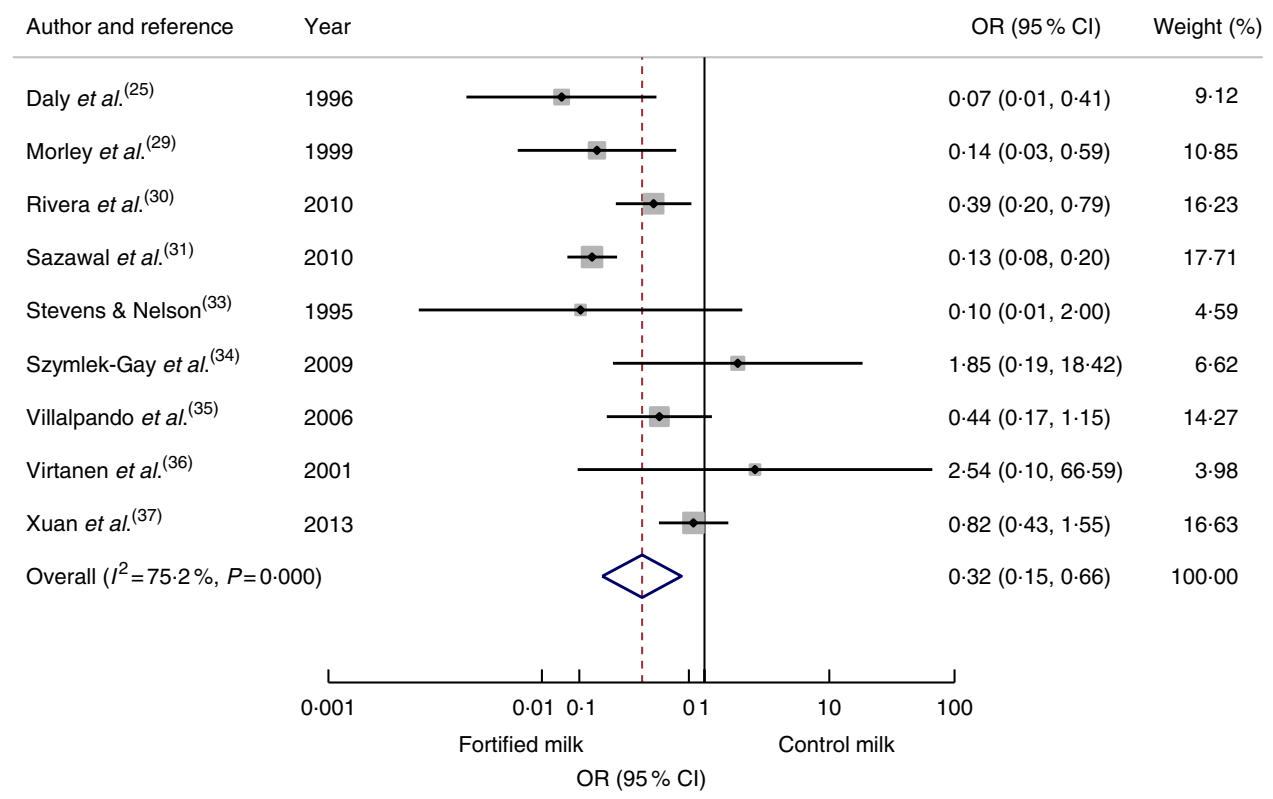

Fig. 3 (colour online) Forest plot: odds of anaemia with fortified milk compared with control milk among 6-47-month-old children. The study-specific OR and $95 \% \mathrm{Cl}$ are represented by the black dot and horizontal line, respectively; the area of the grey square is proportional to the specific-study weight to the overall meta-analysis. The centre of the open diamond/vertical dashed line represents the pooled OR difference and the width of the diamond represents the pooled $95 \% \mathrm{Cl}$. The solid vertical line represents no effect

Table 3 Risk of bias within studies using the modified Cochrane Collaboration's tool for assessing risk of bias in randomised trials

\begin{tabular}{|c|c|c|c|c|c|c|c|c|c|}
\hline \multirow[b]{2}{*}{ Study } & \multicolumn{2}{|c|}{ Selection bias } & \multirow{2}{*}{$\begin{array}{c}\begin{array}{c}\text { Performance } \\
\text { bias }\end{array} \\
\begin{array}{c}\text { Blinding of } \\
\text { participants } \\
\text { and personnel }\end{array}\end{array}$} & \multirow{2}{*}{$\begin{array}{c}\begin{array}{c}\text { Detection } \\
\text { bias }\end{array} \\
\begin{array}{c}\text { Blinding of } \\
\text { outcome of } \\
\text { assessment }\end{array}\end{array}$} & \multicolumn{3}{|c|}{ Attrition bias } & \multirow{2}{*}{$\begin{array}{c}\begin{array}{c}\text { Reporting } \\
\text { bias }\end{array} \\
\\
\text { Selective } \\
\text { reporting }\end{array}$} & \multirow{2}{*}{$\begin{array}{c}\begin{array}{c}\text { Other } \\
\text { bias }\end{array} \\
\\
\text { Funding } \\
\text { source } \dagger\end{array}$} \\
\hline & $\begin{array}{l}\text { Adequate } \\
\text { sequence } \\
\text { generation }\end{array}$ & $\begin{array}{c}\text { Allocation } \\
\text { concealment }\end{array}$ & & & $\begin{array}{l}\text { Exclusion } \\
\text { criteria }\end{array}$ & $\begin{array}{l}\text { Attrition } \\
\text { details }\end{array}$ & $\begin{array}{l}\text { Baseline } \\
\text { imbalance* }^{*}\end{array}$ & & \\
\hline $\begin{array}{l}\text { Chatchatee et al. } \\
(2014)^{(24)}\end{array}$ & + & + & + & + & + & + & - & + & + \\
\hline Daly et al. $(1996)^{(25)}$ & $?$ & - & - & - & + & + & + & + & $?$ \\
\hline $\begin{array}{l}\text { Firmansyah et al. } \\
\qquad(2011)^{(26)}\end{array}$ & + & + & + & + & + & + & + & + & + \\
\hline $\begin{array}{l}\text { Houghton et al. } \\
\qquad(2011)^{(27)}\end{array}$ & + & + & + & + & + & $?$ & $?$ & + & + \\
\hline Morgan et al. (2010) & + & + & + & + & + & + & $?$ & + & + \\
\hline Morley et al. (1999) & + & + & + & + & + & $?$ & + & + & $?$ \\
\hline Rivera et al. $(2010)^{(30)}$ & $?$ & + & + & + & - & + & $?$ & + & + \\
\hline Sazawal et al. (2010) & + & + & + & + & + & + & + & + & + \\
\hline Sazawal et al. (2010) & + & + & + & + & + & + & + & + & + \\
\hline Singhal et al. (2000) ${ }^{(32)}$ & + & + & + & + & + & $?$ & + & + & $?$ \\
\hline $\begin{array}{l}\text { Stevens and Nelson } \\
(1995)^{(33)}\end{array}$ & $?$ & $?$ & + & + & + & + & + & + & $?$ \\
\hline $\begin{array}{l}\text { Szymlek-Gay et al. } \\
(2009)^{(34)}\end{array}$ & + & + & + & + & + & + & $?$ & + & + \\
\hline $\begin{array}{l}\text { Villalpando et al. } \\
\qquad(2006)^{(35)}\end{array}$ & - & + & + & + & - & + & + & + & $?$ \\
\hline Virtanen et al. (2001) & + & - & + & + & + & + & $?$ & + & + \\
\hline Xuan et al. $(2013)^{(37)}$ & $?$ & $?$ & + & $?$ & + & + & + & + & + \\
\hline
\end{tabular}

+ , low risk; - , high risk or not reported; ?, unclear/unsure.

*Baseline imbalance includes the number in each group and other imbalances between groups.

†lf author/s declared that they have no conflict of interest, the article is deemed free of funding source bias.

incomplete outcome data, but two articles did not state the exclusion criteria $^{(30,35)}$ and two did not provide attrition details ${ }^{(27,32)}$. All articles reported primary and secondary outcomes. The studies were also reviewed for publication bias. Most studies reported any baseline imbalance between groups. Four articles (two studies) $)^{(27,28,30,34)}$ had imbalance in the number of participants in the intervention and control group. Three studies had potential baseline 
imbalances, i.e. weight and length ${ }^{(24)}$, biochemical status ${ }^{(28,36)}$, but none were deemed sufficiently extreme to have impacted the study outcome significantly. Only two articles clearly stated that the determined sample size was met ${ }^{(24,32)}$. Risk of bias across studies was investigated by producing a funnel plot from the odds ratio of anaemia at the end of intervention; the funnel plot showed symmetry, indicating minimal publication bias (data not shown).

\section{Sensitivity analysis}

Sensitivity analysis was conducted for studies that were deemed as low risk of bias, fulfilling more than five out of six of the Cochrane quality assessment criteria. Among the studies considered low risk of bias ${ }^{(24,26,31,38)}$, the mean weight gain among the intervention group compared with the control group was $0 \cdot 12 \mathrm{~kg}(95 \%$ CI $0 \cdot 03,0 \cdot 21 \mathrm{~kg})$, but an increase in height was not statistically significant. In studies that reported biomarkers of Fe, two articles were deemed as low risk of bias ${ }^{(31,34)}$, but it was not feasible to produce meta-analysis with two articles.

\section{Discussion}

The present systematic review investigated the effect of fortified milk compared with control milk on the growth and nutritional status of young children. Even though the included studies displayed substantial statistical heterogeneity, we identified some trends in growth parameters and biochemical markers among children in the intervention group.

The overall effect of fortified milk on weight and height gain among children in the intervention groups compared with control groups was minimal, suggesting fortified milk does not adversely affect growth. Importantly, evidence presented here suggests that fortified milk does not promote rapid growth or weight gain, which is known to be associated with later overweight and obesity ${ }^{(40)}$. Growth outcomes were slightly higher in studies conducted in developing economies, possibly because these children generally experience compromised growth and development due to dietary inadequacy ${ }^{(41)}$. In these countries, milk fortification is often part of a public health intervention programme; indeed, four articles included in the current review were evaluating such programmes ${ }^{(30,31,35,38)}$.

Developing countries in Asia account for more than half of the total stunted children in the world ${ }^{(42)}$. Studies from Asia included in the current review identified that fortified milk may be contributing to normal growth potential in young children ${ }^{(26,31,38)}$. Stunting in childhood is associated with impaired health and long-term cognitive development, and therefore is one of the major public health priorities $^{(43)}$. Further, in the Indian study ${ }^{(38)}$, the intervention group receiving milk with added synbiotics had greater weight gain and weight velocity. The authors suggest that this may be due to reduced incidence of gastrointestinal disorders or improved nutrient absorption through regeneration of gut epithelium as a result of improved gut microbiota profiles. The role of gut microbiota in immune system development is well established $^{(44)}$ and nutritional status is closely associated with immune function. Two other Asian studies ${ }^{(26,37)}$ investigating the effect of milk fortified with synbiotics were based on the premise that synbiotics support immune function leading to improved health, thereby promoting normal growth in young children. These studies also observed statistically significant weight gain among the intervention group receiving milk fortified with synbiotics. However, as the role of probiotics is strain- and speciesspecific, effectiveness of probiotics on growth outcomes cannot be generalised from results of these studies alone.

The reviewed studies indicate that children consuming milk fortified with Fe had improved Fe status, even though milk is consumed only as part of a whole diet in young children. Fe deficiency is prevalent among young children, not only in developing economies but also in developed economies ${ }^{(45-47)}$. In developing economies, food fortification is one of many strategies used to address undernutrition. Supplementation programmes have proven effective to address micronutrient deficiencies in developing economies; however, adverse effects of supplementation with $\mathrm{Fe}$ tablets have been reported in regions with high prevalence of malaria ${ }^{(48)}$. Therefore, milk fortified with Fe and other micronutrients may be a safer alternative for addressing nutrient deficiencies with less risk of overdose and, to date, there has not been any report of serious adverse effects of fortified milk ${ }^{(17)}$.

A recent Australian study on Fe intake identified a lack of adequate Fe-rich complementary foods consumed among young children ${ }^{(49)}$. Efforts to raise public awareness of the importance of Fe-rich complementary foods are essential. However, availability of such foods is scarce in developing economies. Furthermore, the New Zealand study $^{(27,28,34)}$ reviewed here included an intervention group receiving red meat; however, groups receiving milk had a significantly higher compliance rate compared with the meat group. The adherence rates to intervention were 81.4 and $89.4 \%$ for the milk groups, whereas only $3.4 \%$ of the meat group consumed the recommended two study meat dishes per day. These results highlight potential difficulties in achieving desirable $\mathrm{Fe}$ intake from normal diet alone during the transition period for some children. In addition, a US-based study identified that fortified foods and drinks are major contributors to nutrient intakes of US children and adolescents ${ }^{(50)}$. Together, evidence presented here supports the effectiveness of fortified milk under certain circumstances.

\section{Limitations}

The present systematic review and meta-analysis provided robust evaluation of RCT investigating the effect of fortified milk in diverse settings, but there are several 
limitations. The included studies were heterogeneous and, therefore, it is difficult to determine the effective level or combination of fortification. A general trend in positive outcomes for serum Fe markers is in line with two previous systematic reviews and meta-analyses of fortified foods, including milk, in young children ${ }^{(51,52)}$. Inclusion of RCT published in the English language only may have introduced bias.

Despite the benefit of reduction in anaemia, fortified milk costs more than regular milk. However, Fe-deficiency anaemia remains the leading cause of years lived with disability among children and adolescents ${ }^{(53)}$. To date, there has not been any economic evaluation conducted specifically for using fortified milk in anaemia reduction. Plessow et al. ${ }^{(54)}$ evaluated the cost-effectiveness of fortified cereal to reduce Fe-deficiency anaemia in 6-23month-old children in India, and identified that fortified cereal is cost-effective to reduce the social costs of Fedeficiency anaemia even if it is heavily subsidised. A review of various Fe fortification programmes in Brazil also demonstrated that the use of fortified milk was twenty-five times more cost-effective considering the estimated mean productivity loss due to Fe-deficiency anaemia $^{(55)}$

Young children are consuming milk as part of a whole diet; it is difficult to determine whether improved growth and nutritional outcomes were specifically due to fortified milk or other factors such as dietary intake. However, studies that investigated dietary intake reported no differences between the intervention and control groups in dietary intake $e^{(24,25,27-29,32,33,34,36)}$, suggesting the only point of difference between the groups was fortified milk consumption. Due to a limited number of studies, it was not possible to fully evaluate the effect on milk fortification of other key nutrients such as vitamin D in the current systematic review. However, observational studies have also identified improved nutrient intakes, including Fe and vitamin $\mathrm{D}$, from fortified milk ${ }^{(19,56,57)}$. In diet-related trials, compliance and leakage can be an issue, and compliance is often based on self-reports. These are common issues experienced in any trial, including studies included in the present review, which may have impacted the observed results. None of the studies included in the review were longer than 12 months in duration. Longer-term follow-up is important to assess other health, clinical and functional outcomes of using the fortified milk products.

\section{Implications for future research and practice}

There is an association between cow's milk consumption and diminishing Fe stores among infants and young children ${ }^{(58)}$. In the UK-based studies included in the current systematic review ${ }^{(25,29,32,33)}$, children in the control group were receiving cow's milk before 12 months of age. Removing these studies resulted in an attenuated result of anaemia reduction. A recent systematic review has identified that infants consuming cow's milk have a higher risk of Fe-deficiency anaemia compared with those consuming Fe-fortified formula milk ${ }^{(59)}$. These results highlight the importance of establishing clear recommendations regarding not giving cow's milk as the main source of drink before 12 months of age and avoiding excessive consumption of cow's milk after 12 months of age.

A growing body of evidence is indicating that higher protein consumption in early life is associated with increased risk of overweight later in life ${ }^{(13,14,60)}$. Only four articles (two studies) $)^{(26-28,34)}$ included in the current systematic review used intervention milk with a distinctively lower protein content compared with cow's milk, but none of these studies assessed body composition. Future trials using more sophisticated laboratory-based body composition assessment methods, such as dualenergy X-ray absorptiometry, may provide more accurate measures of potential differences in body composition between children consuming different types of milk. Recently, a panel of experts in early nutrition developed a recommendation on the composition of fortified follow-up formula for young children based on common deficiencies, to be adapted in each country ${ }^{(18)}$. This recommendation may assist in developing fortified milk that is more uniform in composition, based on scientific evidence.

The role of the human gut microbiota in health has been the subject of considerable scientific interest and research. Diet, by far, is the most important factor that influences the gut microbiota population. Prebiotics, probiotics, or in combination as synbiotics, are used as strategies to improve the composition of the gut microbiota. Fortifying milk with synbiotics in the studies included in the present review was based on the understanding of the interrelationship between gastrointestinal function, the immune system and nutritional status, which ultimately affects growth in children. Although an increasing amount of research is indicating that gut microbiota development is proceeding until about 3 years of age or even longer ${ }^{(61,62)}$, there is still a paucity of research on gut microbiota development beyond the first year of life. The function of milk containing prebiotics and/or probiotics for young children over 12 months of age should, therefore, be further investigated, together with close monitoring of the potential effect on the gut microbial profile, health and growth outcomes, and dietary intake analysis.

The present systematic review and meta-analysis identified that consuming fortified milk can improve certain aspects of nutritional status, particularly $\mathrm{Fe}$, in young children. Considering that Fe deficiency is the most common nutrient deficiency among children in the world, it is an important public health concern to be addressed. Undoubtedly, if children are consuming a balanced and varied diet, fortified milk is not necessary. However, when adequate nutritious complementary foods are unavailable or fussy eating behaviour is prevalent during dietary 
transition, children may not be meeting nutritional requirements for optimal growth and development. Under such circumstances, fortified milk may be a safe, acceptable and effective source of complementary nutrition to supplement those children in need, when consumed in appropriate amounts in addition to a normal diet, until a better dietary habit can be established. New recommendations on the composition of fortified milk for children over 12 months of age are now available, and further welldesigned RCT incorporating follow-up beyond 12 months of duration are warranted to investigate the benefit of fortified milk on growth and nutritional outcomes in young children.

\section{Acknowledgements}

Financial support: This research received no specific grant from any funding agency in the public, commercial or not-for-profit sectors. M.M. is supported by the Australian Government Post Graduate Award Scholarship. R.J.H. is partially funded by Danone Nutricia. Conflict of interest: The authors declare that they have no conflict of interest. Authorship: M.M. designed the study and wrote the manuscript. M.M. conducted the electronic database search and extracted titles, abstracts and articles. M.M. and T.H. screened and selected articles. M.M. extracted data. T.H. and R.J.H. verified the extracted data. M.M. conducted metaanalyses and M.D. provided biostatistics support. T.H., M.D., R.J.H. and P.S.W.D. read and commented on the manuscript. All authors read and approved the final manuscript. Ethics of human subject participation: Not applicable.

\section{References}

1. Picciano MF, Smiciklas-Wright H, Birch LL et al. (2000) Nutritional guidance is needed during dietary transition in early childhood. Pediatrics 106, 109-114.

2. Dovey TM, Staples PA, Gibson EL et al. (2008) Food neophobia and 'picky/fussy' eating in children: a review. Appetite 50, 181-193.

3. Falciglia GA, Couch SC, Gribble LS et al. (2000) Food neophobia in childhood affects dietary variety. J Am Diet Assoc 100, 1474-1481.

4. Galloway AT, Lee Y \& Birch LL (2003) Predictors and consequences of food neophobia and pickiness in young girls. J Am Diet Assoc 103, 692-698.

5. Fox MK, Reidy K, Novak T et al. (2006) Sources of energy and nutrients in the diets of infants and toddlers. J Am Diet Assoc 106, 1 Suppl. 1, S28-S42.

6. Webb K, Rutishauser I \& Knezevic N (2008) Foods, nutrients and portions consumed by a sample of Australian children aged 16-24 months. Nutr Diet 65, 56-65.

7. Domellof M, Braegger C, Campoy C et al. (2014) Iron requirements of infants and oddlers. J Pediatr Gastroenterol Nutr 58, 119-129.

8. Grant CC, Wall CR, Crengle S et al. (2009) Vitamin D deficiency in early childhood: prevalent in the sunny South Pacific. Public Health Nutr 12, 1893-1901.

9. Munns CF, Simm PJ, Rodda CP et al. (2012) Incidence of vitamin D deficiency rickets among Australian children: an
Australian Paediatric Surveillance Unit study. Med J Aust 196, 466-468.

10. Meyer BJ \& Kolanu N (2011) Australian children are not consuming enough long-chain omega-3 polyunsaturated fatty acids for optimal health. Nutrition 27, 1136-1140.

11. Zhou SJ, Gibson RA, Gibson RS et al. (2012) Nutrient intakes and status of preschool children in Adelaide, South Australia. Med J Aust 196, 696-700.

12. Michaelsen KF \& Greer FR (2014) Protein needs early in life and long-term health. Am J Clin Nutr 99, issue 3, 718S-722S.

13. Gunther ALB, Buyken AE \& Kroke A (2006) The influence of habitual protein intake in early childhood on BMI and age at adiposity rebound: results from the DONALD Study. Int J Obes (Lond) 30, 1072-1079.

14. Rolland-Cachera MF, Deheeger M, Akrout M et al. (1995) Influence of macronutrients on adiposity development: a follow up study of nutrition and growth from 10 months to 8 years of age. Int J Obes Relat Metab Disord 19, 573-578.

15. World Health Organization (2016) Childhood overweight and obesity. http://www.who.int/dietphysicalactivity/ childhood/en/ (accessed May 2016).

16. World Health Organization (2013) Essential Nutrition Actions: Improving Maternal, Newborn, Infant and Young Child Health and Nutrition. Geneva: WHO.

17. Vandenplas Y, De Ronne N, Van De Sompel A et al. (2014) A Belgian consensus-statement on growing-up milks for children 12-36 months old. Eur J Pediatr 173, 1365-1371.

18. Suthutvoravut U, Abiodun PO, Chomtho S et al. (2015) Composition of follow-up formula for young children aged 12-36 months: recommendations of an International Expert Group Coordinated by the Nutrition Association of Thailand and the Early Nutrition Academy. Ann Nutr Metab 67, 119-132.

19. Walton J \& Flynn A (2013) Nutritional adequacy of diets containing growing up milks or unfortified cow's milk in Irish children (aged 12-24 months). Food Nutr Res 2013, 57.

20. Moher D, Liberati A, Tetzlaff J et al. (2009) Preferred reporting items for systematic reviews and meta-analyses: the PRISMA statement. Ann Intern Med 151, 264-269.

21. Higgins JP, Altman DG, Gotzsche PC et al. (2011) The Cochrane Collaboration's tool for assessing risk of bias in randomised trials. BMJ 343, d5928.

22. Bland M (2000) An Introduction to Medical Statistics, 3rd ed. New York: Oxford University Press.

23. United Nations (2015) World Economic Situation and Prospects 2015. New York: UN.

24. Chatchatee P, Lee WS, Carrilho E et al. (2014) Effects of growing-up milk supplemented with prebiotics and LCPUFAs on infections in young children. J Pediatr Gastroenterol Nutr 58, 428-437.

25. Daly A, MacDonald A, Aukett A et al. (1996) Prevention of anaemia in inner city toddlers by an iron supplemented cows' milk formula. Arch Dis Child 75, 9-16.

26. Firmansyah A, Dwipoerwantoro PG, Kadim M et al. (2011) Improved growth of toddlers fed a milk containing synbiotics. Asia Pac J Clin Nutr 20, 69-76.

27. Houghton LA, Gray AR, Szymlek-Gay EA et al. (2011) Vitamin D-fortified milk achieves the targeted serum 25-hydroxyvitamin D concentration without affecting that of parathyroid hormone in New Zealand toddlers. J Nutr 141, 1840-1846.

28. Morgan EJ, Heath ALM, Szymlek-Gay EA et al. (2010) Red meat and a fortified manufactured toddler milk drink increase dietary zinc intakes without affecting zinc status of New Zealand toddlers. J Nutr 140, 2221-2226.

29. Morley R, Abbott R, Fairweather-Tait $S$ et al. (1999) Iron fortified follow on formula from 9 to 18 months improves iron status but not development or growth: a randomised trial. Arch Dis Child 81, 247-252.

30. Rivera JA, Shamah T, Villalpando S et al. (2010) Effectiveness of a large-scale iron-fortified milk distribution program 
on anemia and iron deficiency in low-income young children in Mexico. Am J Clin Nutr 91, 431-439.

31. Sazawal S, Dhingra U, Dhingra P et al. (2010) Micronutrient fortified milk improves iron status, anemia and growth among children 1-4 years: a double masked, randomized, controlled trial. PLoS One 5, e12167.

32. Singhal A, Morley R, Abbott R et al. (2000) Clinical safety of iron-fortified formulas. Pediatrics 105, E38.

33. Stevens D \& Nelson A (1995) The effect of iron in formula milk after 6 months of age. Arch Dis Child 73, 216-220.

34. Szymlek-Gay EA, Ferguson EL, Heath ALM et al. (2009) Food-based strategies improve iron status in toddlers: a randomized controlled trial. Am J Clin Nutr 90, 1541-1551.

35. Villalpando S, Shamah T, Rivera J et al. (2006) Fortifying milk with ferrous gluconate and zinc oxide in a public nutrition program reduced the prevalence of anemia in toddlers. J Nutr 136, 2633-2637.

36. Virtanen M, Svahn C, Viinikka L et al. (2001) Iron-fortified and unfortified cow's milk: effects on iron intakes and iron status in young children. Acta Paediatr 90, 724-731.

37. Xuan NN, Wang D, Grathwohl D et al. (2013) Effect of a growing-up milk containing synbiotics on immune function and growth in children: a cluster randomized, multicenter, double-blind, placebo controlled study. Clin Med Insights Pediatr 7, 49-56.

38. Sazawal S, Dhingra U, Hiremath G et al. (2010) Effects of Bifidobacterium lactis HN019 and prebiotic oligosaccharide added to milk on iron status, anemia, and growth among children 1 to 4 years old. J Pediatric Gastroenterol Nutr $\mathbf{5 1}$, 341-346.

39. WHO Multicentre Growth Reference Study Group (2006) WHO Child Growth Standards based on length/height, weight and age. Acta Paediatr Suppl 450, 76-85.

40. Brisbois TD, Farmer AP \& McCargar LJ (2012) Early markers of adult obesity: a review. Obes Rev 13, 347-367.

41. Lunn PG (2002) Growth retardation and stunting of children in developing countries. Br J Nutr 88, 109-110.

42. Black R, Allen L, Bhutta Z et al. (2008) Maternal and child undernutrition: global and regional exposures and health consequences. Lancet 371, 243-260.

43. Dewey KG \& Begum K (2011) Long-term consequences of stunting in early life. Matern Child Nutr 7, Suppl. 3, 5-18.

44. Kamada N \& Nunez G (2014) Regulation of the immune system by the resident intestinal bacteria. Gastroenterology 146, 1477-1488.

45. Uijterschout L, Vloemans J, Vos R et al. (2014) Prevalence and risk factors of iron deficiency in healthy young children in the southwestern netherlands. I Pediatric Gastroenterol Nutr 58, 193-198.

46. Grant CC, Wall CR, Brunt D et al. (2007) Population prevalence and risk factors for iron deficiency in Auckland, New Zealand. J Paediatr Child Health 43, 532-538.

47. Looker AC, Dallman PR, Carroll MD et al. (1997) Prevalence of iron deficiency in the United States. JAMA 277, 973-976.

48. Sazawal S, Black RE, Ramsan M et al. (2006) Effects of routine prophylactic supplementation with iron and folic acid on admission to hospital and mortality in preschool children in a high malaria transmission setting: communitybased, randomised, placebo-controlled trial. Lancet $\mathbf{3 6 7}$, $133-143$

49. Atkins LA, McNaughton SA, Campbell KJ et al. (2016) Iron intakes of Australian infants and toddlers: findings from the Melbourne Infant Feeding, Activity and Nutrition Trial (InFANT) Program. Br J Nutr 115, 285-293.

50. Berner LA, Keast DR, Bailey RL et al. (2014) Fortified foods are major contributors to nutrient intakes in diets of US children and adolescents. I Acad Nutr Diet 114, 1009-1022.e8.

51. Eichler K, Wieser S, Ruthemann I et al. (2012) Effects of micronutrient fortified milk and cereal food for infants and children: a systematic review. BMC Public Health 12, 506.

52. Athe R, Rao MV \& Nair KM (2014) Impact of iron-fortified foods on $\mathrm{Hb}$ concentration in children ( $<10$ years): a systematic review and meta-analysis of randomized controlled trials. Public Health Nutr 17, 579-586.

53. Kyu HH, Pinho C, Wagner JA et al. (2016) Global and national burden of diseases and injuries among children and adolescents between 1990 and 2013: findings from the Global Burden of Disease 2013 Study. JAMA Pediatr 170, 267-287.

54. Plessow R, Arora NK, Brunner B et al. (2016) Costeffectiveness of price subsidies on fortified packaged infant cereals in reducing iron deficiency anemia in 6-23-month-old-children in urban India. PLOS ONE 11, e0152800.

55. Beinner MA \& Lamounier JA (2003) Recent experience with fortification of foods and beverages with iron for the control of iron-deficiency anemia in Brazilian children. Food Nutr Bull 24, 268-274.

56. Ghisolfi J, Vidailhet M, Fantino M et al. (2011) Cows' milk or growing-up milk: what should we recommend for children between 1 and 3 years of age? Arch Pediatr 18, 355-358.

57. Sidnell A, Pigat S, Gibson S et al. (2016) Nutrient intakes and iron and vitamin D status differ depending on main milk consumed by UK children aged 12-18 months - secondary analysis from the Diet and Nutrition Survey of Infants and Young Children. J Nutr Sci 5, e32.

58. Ziegler EE (2011) Consumption of cow's milk as a cause of iron deficiency in infants and toddlers. Nutr Rev 69, Suppl. 1, S37-S42.

59. Griebler U, Bruckmuller MU, Kien C et al. (2016) Health effects of cow's milk consumption in infants up to 3 years of age: a systematic review and meta-analysis. Public Health Nutr 19, 293-307.

60. Ohlund I, Hernell O, Hornell A et al. (2010) BMI at 4 years of age is associated with previous and current protein intake and with paternal BMI. Eur J Clin Nutr 64, 138-145.

61. Agans R, Rigsbee L, Kenche H et al. (2011) Distal gut microbiota of adolescent children is different from that of adults. FEMS Microbiol Ecol 77, 404-412.

62. Ringel-Kulka T, Cheng J, Ringel Y et al. (2013) Intestinal microbiota in healthy US young children and adults - a high throughput microarray analysis. PLoS One 8, e64315. 